\title{
Implementation of Teacher Certification in SD Negeri 11 Air Kumbang to Improve Teacher Performance
}

\author{
Mega Yati ${ }^{1 *}$, Edi Harapan², Dessy Wardiah ${ }^{2}$ \\ ${ }^{1}$ SD Negeri 11 Air Kumbang, South of Sumatera, Indonesia \\ ${ }^{2}$ Universitas PGRI Palembang, Indonesia \\ "Corresponding author.Email: megayati3593@gmail.com
}

\begin{abstract}
Using descriptive qualitative research methods, this study aims to identify and describe the Implementation of Teacher Certification in Improving Teacher Performance at 11 Air Kumbang State Elementary Schools. The qualitative descriptive research design used in this study is intended to describe and analyze teacher certification implementation, specifically to obtain an overview of the relationship between teacher certification and teacher performance. Data collection techniques in this study through interviews, observation, documentation and triangulation. The research results show that the implementation of certification on teacher performance in lesson planning, learning implementation, and learning evaluation has been carried out well and optimally in 11 Air Kumbang State Elementary School.
\end{abstract}

Keywords: Implementation, Certification, Performance

\section{INTRODUCTION}

Education is something that is really needed by humans. so that education plays an important role in one's life. Because with the existence of education will make a change in the individual towards the better. In educational institutions there is a teaching and learning process which is a means of achieving an outcome from an education. The teacher as an educator must be able to carry out a fun learning process and be able to motivate students so that it will automatically encourage the emergence of positive activities of students in learning. In carrying out the activities of the teaching and learning process, activities that can support these learning activities are needed so that the predetermined goals can be achieved properly as well. To achieve this, it requires the participation of a teacher as an educator who directly interacts with students. Teachers are professionals, as mandated by Law No. 20 of 2003 Concerning the National Education System, Law Recognition of the professional ability of teachers must be directed not only at coaching, which is more in the nature of personnel administrative aspects, but also toward increasing their professional abilities and commitment as educators.

In the context of increasing the professional ability of teachers, certification and periodic competency tests are required to ensure that motivation and performance continue to improve while meeting professional standards. The government has made numerous efforts to fulfill the mandate of regulations to improve the quality and welfare of teachers through teacher certification. One of them is the regulation regarding the allocation of professional teacher allowances [1]. Certification is to get good and professional teachers, who have the competence to carry out the functions and goals of the school in particular, as well as the goals of education in general, according to the needs of society and the demands of the times.

An effort to ensure the quality of teachers in order to still meet competency standards requires an adequate mechanism [2]. This teacher quality assurance needs to be developed based on a comprehensive assessment to produce a conceptual and empirical basis, through a system of certification. Jalal stated that the teacher certification process towards the professionalization of the implementation of their duties and functions must be accompanied by an increase in teacher health, teacher welfare and measured by the salary and incentives received. Salaries and allowances for teachers in Indonesia are relatively low compared to other countries. Low teacher welfare can affect motivation, teacher performance, spirit of dedication and efforts to develop professionalism.

Teachers are expected to provide and realize the hopes and desires of all parties, particularly the general public, who have placed their trust in schools and teachers to foster students. The performance of teachers in carrying out their duties has a strong influence on achieving good quality education, so teacher performance is an important requirement for achieving 
educational success. In general, high-quality education serves as a barometer for teacher performance success. The performance of teachers in schools is critical to achieving school goals. Various parties are focusing on performance issues because government performance is felt by the community and teacher performance is felt by students or parents, so various efforts are made to achieve good performance.

The teacher is one of the determining factors for the high and low quality of educational outcomes. The extent to which teachers are prepared to prepare their students through teaching and learning activities determines the success of education providers. However, teacher performance in the classroom and their level of well-being has a strong influence on teachers' strategic position to improve the quality of educational outcomes.

From the observations at SD Negeri 11 Air Kumbang, out of 14 teachers, only 5 of them have received certification, it was found that some teachers consider certification and obtaining allowances to be the main goal, even though certification is actually a means or instrument to achieve a goal, not an end in itself. Some teachers even stated that their level of motivation, level of competence, and level of performance had not changed much. This phenomenon shows that certification and teacher professional allowances have not fully achieved their goals. In this case the certification itself is considered an objective. Supposedly, if the teacher takes the certification test, the main objective is not to get the professional allowance.

Previous relevant research was carried out by Previous research was also conducted by Imansyah, et al [3] that is, principal leadership has a significant effect on teacher performance at SMA Negeri Muara Enim; school committee participation has a significant effect on teacher performance at SMA Negeri Muara Enim; and principal leadership and school committee participation together have a significant effect on the performance of SMA Negeri teachers in Muara Enim. Similarities This study and previous research both assessed teacher performance while the difference lies in the research method used.

Previous research has also been conducted by Murwati [4], based on the findings of the data analysis and hypothesis testing described previously, it is possible to conclude that professional certification has an effect on teacher work motivation at State Vocational High Schools in Surakarta, as evidenced by the $t$ test results. At the $5 \%$ level of significance, tcount $>$ ttable, namely $10.641>1.664$. The second conclusion is that there is an effect of professional certification on the performance of teachers in State Vocational High Schools in Surakarta, this can be seen from the results of the $\mathrm{t}$ test, which is tcount $>$ ttable, namely 8.226>1.664 at the 5\% significance level. Differences and similarities in Murwati's research.
Previous research was also conducted [8] that can be concluded that there is a significant influence between the professional competence of certified teachers on teacher performance at SMP Negeri 1 Surabaya. The effect of the variable professional competence on the teacher performance variable (X1-Y) is answered using multiple regression which shows the value of $t=2.850$ with a significant value $=0.007<0.05$ so that it can be significant against Y (Teacher Performance).

\section{METHODS}

The research uses qualitative research methods. This method is used by researchers in describing the results of the research while in SD Negeri 11 Air Kumbang. The qualitative approach is a research method used to investigate the condition of a natural object (rather than an experiment) in which the researcher is the primary instrument, data collection is done through triangulation (combined), data analysis is inductive, and qualitative research findings emphasize meaning that instead sweeping generalization [10]. The data criteria in qualitative research definite data. Qualitative research is designed to reveal (understand) what informs measurable actions or results from qualitative research [7]. This method is also called an artistic method, because the research process is more artistic (less patterned) and is called an interactive method because the research data is more concerned with the interpretation of data found in the field [8]. In this research, data collection techniques were carried out through participatory observation, in-depth interviews, documentation study. Techniques for collecting data include observation, interviews, and documentation.

In this study, in accordance with the character of qualitative research, data analysis will be used using the Miles and Huberman model, where the process starts from data reduction, data display, and consclusion drawing or verification. The next stage is checking and checking the validity of the data. The data validity process was carried out in order to provide an overview of the facts of the data discovered by the researchers in the field [9] the validity test in qualitative research includes testing data credibility (internal validity), transferability (external validity), defendability, and confirmavibility (objectivity).

\section{RESULTS AND DISCUSSION}

The findings of a study on certified teachers' performance in teaching planning show that the performance of certified teachers at SD Negeri 11 Air Kumbang has been adopted. This is demonstrated by the fact that nearly all education certified teachers at SD Negeri 11 Air Kumbang use a lesson planning tool. This learning tool's availability can be said to be complete. This device is already owned by the teacher and has been used in the classroom learning process. Syllabus and lesson plans, annual programs, semester programs, 
SK and KD mapping and evaluation, KKM, teaching materials, analysis, and questions are examples of existing learning tools compiled by certified teacher educators. This is in accordance with the provisions pertaining to the learning device's completeness.

According to the Ministry of National Education, learning activities must be planned and designed to provide learning experiences that include mental and physical processes through relationships between students, students and teachers, the environment, and other learning resources in order to achieve basic competencies. Thus, the teacher's learning planning is critical to the success of students' learning. Therefore, the existence of learning tools that are compiled at the beginning and compiled by the teacher is important in a learning activity.

This is very reasonable, of course, because it is the teacher who is most familiar with the students, the environment, and the learning resources available at school. The Ministry of Religion of the Republic of Indonesia said that «the teacher is in charge of providing instruction in schools. He delivered lessons so that students understand well all the knowledge conveyed ». The Ministry of National Education stated that «The intended learning activities can be realized through the use of a variety of student-centered learning approaches. It can be said that the availability of learning facilities at SD Negeri 11 Air Kumbang is adequate. As for the room, in addition to having sufficient study rooms, this school also has quite good library facilities.

Certified teachers of educators in this school have taken advantage of the existing learning facilities and infrastructure by using them in learning, especially learning tools and media. From the above conditions, it is clear that in terms of infrastructure, which influences the learning process being carried out, SD Negeri 11 Air Kumbang has a complete existence. Every school is indeed required to have adequate and adequate facilities and infrastructure for the number of students. Regarding these infrastructure [4]. It is hoped that there will be adequate learning tools or facilities that are quantitative, qualitative and relevant to needs and can be used optimally for the benefit of the education and teaching process".

By seeing the importance of learning carried out by teachers in preparing students both cognitively, affective and psychomotor, it becomes a necessity for every teacher, especially for certified teachers to be able to compile their own learning tools. that should be done at the beginning of the semester, so that the teacher will really be ready for his job.In general, from this aspect, certified teacher educators are good at delivering learning. Likewise, in choosing teaching materials, certified teachers of SD Negeri 11 Air Kumbang also understand that in determining the teaching materials given to students, it is necessary to choose the right choice so that it can help students achieve learning objectives and must be clearly conveyed in accordance with the learning hierarchy. The teacher must consider the scope or scope and depth of the learning material so that it is neither less nor more. The order needs to be considered so that learning is coherent. Treatment needs to be chosen precisely so that it is not wrong to teach or learn it. Further research is similar to this research conducted by [5] Murwati (2013), Based on the results of data analysis and hypothesis testing described previously, it is possible to conclude that professional certification has an effect on teacher work motivation at SMK Negeri Surakarta, as evidenced by the t test results obtained by tcount $>\mathrm{t}$ table, namely $10.641>1.664$ at the $5 \%$ significance level. The second conclusion is that there is an effect of professional certification on the performance of teachers in State Vocational High Schools in Surakarta, this can be seen from the results of the $\mathrm{t}$ test, which is tcount $>$ ttable, namely $8.226>1.664$ at the $5 \%$ significance level.

The similarities and differences in this study lie in the focus of the study, namely both reviewing teacher certification and performance. Whereas the difference between this study and the previous research was located in the research location, the previous research where the research was located in a Vocational High School and the current research was located in an elementary school, besides that, another difference was in the research method used. In previous studies, the research method used was quantitative methods, while current research methods used qualitative methods. Furthermore, previous research conducted by [10] entitled «Implementation of the Teacher Certification Program in Study Offices at Ciparay State Madrasah Aliyah, Bandung Regency». For the techniques or methods used by certified teachers who are educators or who have not been at SD Negeri 11 Air Kumbang, among others, through the provision of additional materials or assignments, and by answering questions raised by the teacher during the learning process

In remedial and follow-up learning activities, it is known that certified teacher teachers are more intense and routine in carrying out remedial activities for students who have not reached learning completeness. In the Ministry of National Education, it is stated that «this activity can be carried out through providing relearning or giving assignments to students. After this activity is carried out, the teacher gives another test related to the relevant $\mathrm{KD} »$. This condition shows the effectiveness of certified teachers who are not yet in SD Negeri 11 Air Kumbang in carrying out remedial activities and follow-up learning.

Furthermore, Implementation of the Teacher Certification Program in Study Offices at Ciparay State Madrasah Aliyah, Bandung Regency» conducted research. The findings revealed that the Ministry of Religion of Bandung Regency's implementation of the 
in-service teacher certification program, particularly for Madrasah Aliyah Negeri Ciparay teachers, was not yet optimum due to a number of obstacles that remained to be overcome. According to the group, there is still a scarcity of human and financial resources. In terms of interpretation, program implementers understand the program goals and guidelines but are inconsistent in carrying out their responsibilities and functions. In terms of application, it was discovered that program implementation oversight was not in place, as evidenced by the absence of an assessment report for the previous year's implementation of the in-service teacher certification program.

\section{CONCLUSION}

Guided by the research findings discussed in the previous chapter, it can be concluded that the implementation of certification on teacher performance in learning planning is seen from the preparation of learning tools by the teacher, the tools compiled are complete and used in the learning process in the classroom. For the availability of learning facilities at SD Negeri 11 Air Kumbang, it is adequate, which aids in the learning process and is employed by the teacher in the learning process, in the implementation of learning seen from the teacher's understanding of task completion in accordance with the time allocation of the subject, has compliance with the allocated time and end learning in accordance with the allocation of time for the subjects taught and have complete learning tools, including evaluation questions, answer keys to evaluation questions, and assessment guidelines. Certified teacher educators have also started learning by making perceptions and having mastery of the subject matter and being able to demonstrate it in the learning process and in learning evaluation, indicated by the availability of learning outcome assessment documents, this is due to the variety of evaluation techniques and methods used and remedial activities and follow-up learning by the teacher.

\section{ACKNOWLEDGMENT}

Our deepest gratitude goes to Teachers in SD Negeri 11 Air Kumbang, Chancellor of Palembang PGRI University, Director of the Postgraduate Program of PGRI Palembang University and the Education Management Study Program of PGRI Palembang University, who have supported us in doing this extraordinary thing. This project is funded independently. We also want to thank our Education Management friends who helped us a lot in a short time frame to complete this project.

\section{REFERENCES}

[1] Mulyasa, E. (2017). Uji Kompetensi dan Penilaian Kinerja Guru [Teacher Competency Test and
Performance Appraisal]. Bandung: PT. Remaja Rosda Karya.

[2] Hanafiah, N., \& Suhana, C. (2012). Konsep Strategi Pembelajaran [Learning Strategy Concept]. Bandung: Refika.

[3] Imansyah., Arafat, Y., \& Wardiah, D. (2020). Pengaruh Kepemimpinan Kepala Sekolah dan Partisipasi Komite Sekolah Terhadap Kinerja Guru [The Influence of Principal Leadership and School Committee Participation on Teacher Performance]. JMKSP (Jurnal Manajemen, Kepemimpinan, dan Supervisi Pendidikan). Vol 5 No 2 P-ISSN:25487094 E-ISSN 2614-802.

[4] Murwati, H. (2013). Pengaruh Sertifikasi Profesi Guru Terhadap Motivasi Kerja dan Kinerja Guru di SMK Negeri SE-SURAKARTA [The Effect of Teacher Professional Certification on Work Motivation and Teacher Performance in SMK Negeri SE-SURAKARTA]. Jurnal Pendidikan Bisnis dan Ekonomi (BISE) Vol.1 No. 1.

[5] Yustiyawan, R. H. (2014). Pengaruh Motivasi dan Kompetensi Guru Profesional Guru Yang bersertifikasi terhadap Kinerja Guru di SMP Negeri [The Influence of Motivation and Competence of Certified Professional Teachers on Teacher Performance in State Junior High Schools]. Jurnal Inspirasi Manajemen Pendidikan, Vol. 3. No. 3, Januari 2014, hlm. 114-123.

[6] Yusuf, B. S. (2017). Implementasi Program Sertifikasi Guru dalam Jabatan (Studi Pada Madrasah Aliyah Negeri Ciparay Kabupaten Bandung [Implementation of Teacher Certification Program in Position (Study at Madrasah Aliyah Negeri Ciparay, Bandung Regency]. Jurnal Administrasi Negara”. Vol. 2 No. 1 Hal 43-50.

[7] Sugiyono. (2019). Metode Penelitian Kuantitatif, Kualitatif dan $R$ \& $D$ [Quantitative Research Methods, Qualitative and $R \& D]$. Bandung; Alfabeta

[8] Aminah., \& Roikan, S. (2019). Pengantar Metode Penelitian Kualitatif Ilmu Politik [Introduction to Qualitative Research Methods in Political Science]. Jakarta: Kencana

[9] Rustanto, B. (2015). Penelitian Kualitatif Pekerjaan Sosial [Qualitative Social Work Research]. Bandung: PT. Remaja Rosdakary

[10] Yusuf, M. (2017). Metode Penelitian: Kuantitatif, Kualitatif dan Penelitian Gabungan [Research Methods: Quantitative, Qualitative and Combined Research]. Jakarta: Kencana. 